The Fifth Scientific Conference of Obour Institutes "Engineering and Informatics for Sustainable Smart Organizations “

\title{
The Effect of the Interaction between the Type of Learning Environment (Face to Face - Online) And the Type of Test (Essay - Bubble Sheet) on The Results of Academic Achievement among Students of Obour Institutes
}

\author{
Dr. Hassan Awad Elgendy ${ }^{1}$, Dr. Zeyad Aly Khalil ${ }^{2}$ \\ ${ }^{1}$ Assistant Professor of Curriculum and Teaching Methods of Mathematics \\ hgendy@oi.edu.eg \\ ${ }^{2}$ Lecturer at Al-Obour Higher Institute for Management and Informatics \\ zeiadaly@oi.edu.eg
}

\begin{abstract}
The aim of the current study is to investigate the effect of the interaction between the type of learning environment (face-toface-online) and the type of test (essay-bubble sheet) on the results of academic achievement. The study sample was distributed to the second-year students of the Management Information Systems division in the course "Principles of Statistics", one of which is taught in a traditional learning environment (face to-face) and the second is taught in an electronic learning environment via the Internet (online), and two types of tests were applied (essay and bubble sheet) for each group after the completion of teaching the course, and the results were analyzed. The results of the study resulted in the superiority of the students of group (2), which was taught in a learning environment (face to-face) and was tested with a type of test (objective with the bubble sheet system), followed by group (4), which was taught in an online learning environment and was tested With a test type (bubble sheet), then group (1), which was taught in a learning environment (face to face) and was tested with a test type (Essay), and finally group (3), which was taught in an (online) learning environment. Test it with a test type (Essay).
\end{abstract}

Keywords: learning environment - test type - essay test - objective test - bubble sheet system - achievement test

\section{Introduction}

Teaching students in a face-to-face learning environment in many educational institutions has been the dominant form of teaching in higher education, Because of the threat of the COVID-19 virus, many of those university and pre-university educational institutions in most countries of the world have faced problems about how to continue teaching and teaching in them while preserving teachers, faculty, staff and students from the threats of infection with the virus, What prompted those countries and their educational institutions to Study for alternative methods to prevent the educational process from stopping, so most of these educational institutions cancelled all classes face to face, and moved towards online education to help prevent the spread of the virus, As well as the shift from the traditional form of tests (essay tests), which required the corrector to correct the answer sheets himself, which may increase his risk of infection with the virus, to another type of test that relies on electronic correction, which is (bubble sheet system), and many studies and literature have differed about the effectiveness of online education (Driscoll et al., 2012), as some studies preferred the traditional (faceto-face) learning environment in the classroom (Atchley et al., 2013), but some studies preferred online learning as They see that students' performance is better than the traditional face-to-face learning environment (Westhuis et al., 2006).

Hence this Study came to know the effectiveness and ability of the online learning environment, as well as 
the type of test in the bubble sheet system to make an impact and achieve the goals of the educational process as an alternative to traditional education and testing.

\section{Study problem:}

With the spread of the Covid-19 virus, most educational institutions were closed as part of the precautionary measures to contain the risks of its spread, and the trend increased towards online learning environments, instead of the traditional learning environment (Face to Face), as well as the shift from the traditional test type (essay) to the type of The objective test using the (Bubble Sheet) system, and with the increasing trend towards online education, as well as the use of the type of objective test using the (Bubble Sheet) system, it was necessary to study the impact of these environments and types on students' achievement and results. Therefore, the Study problem can be crystallized in the following main question:

- What is the effect of the interaction between the type of learning environment (face to face online) and the type of test (essay - objective in the bubble sheet system) on the results of academic achievement among students of Obour institutes?

From this main question, the following questions arise:

1) What is the effect of the different learning environment type (face to face - online) on the results of academic achievement among students of Obour institutes?

2) What is the effect of the difference in the test type (essay - bubble sheet) on the results of the academic achievement of the students of Obour institutes?

3) What is the effect of the difference in the learning environment type (face to face - online) and the test type (essay - bubble sheet), on the results of academic achievement among students of transit institutes?
Objective limits:

- Spatial boundaries: Obour Higher Institute for Management, Computers and Information Systems.

- Human limits: second year students majoring in management information systems.

- Two types of learning environments (face to face online).

- Two types of tests (essay - bubble sheet).

- Academic achievement results (as a dependent variable).

Study Tools:

"Principles of Statistics" course.

The following tools were used in this Study:

- An achievement test designed with two types of tests: (essay - bubble sheet), for the cognitive aspect related to the "Principles of Statistics" course.

\section{Methodology:}

The current Study relied on the use of the following two approaches:

1) Analytical descriptive approach: in reviewing the Study literature and related studies, in order to benefit from the references to build the theoretical background of the Study topic.

2) Semi-experimental approach: to identify the effect of the two independent variables and the interaction between them on the dependent variable.

\section{Variables:}

The Study included a set of variables:

1) First- the independent variables:

a) Learning environment (face to face - online).

b) The test type (essay - bubble sheet).

2) Second- Dependent variables: Academic achievement results.

\section{Experimental design:}

Table (1): Experimental design of the research

Study Aims:

- The aim of the current Study is to investigate the effect of the interaction between the learnir environment (face to face - online) and the type of test (essay - bubble sheet) on the results of academic achievement among students of transit institutes.

\section{Study Importance:}

The importance of the Study is determined by the following:

- It is expected that the current Study will provide results that help those in charge of the educational process towards a better learning environment after the end of the Corona epidemic.

- Providing assistance to those in charge of the educational process towards the best type of test

Study Limits: after the end of the Corona epidemic.

The Study was limited to the following limits:

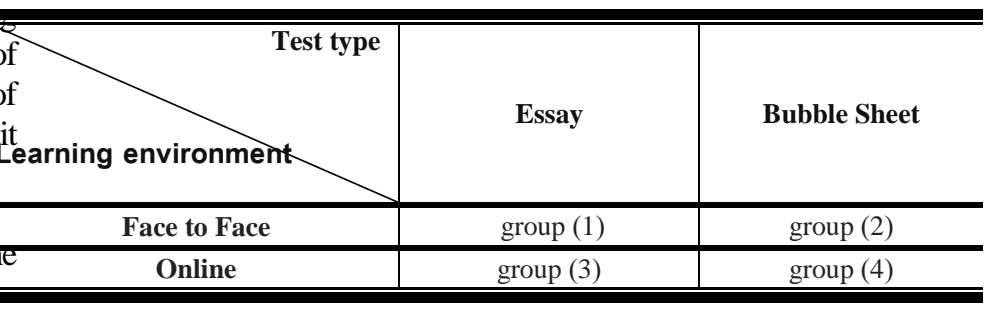

\section{Terminology}

\section{- Learning environment:}

The current research defines it procedurally as the way in which the "Principles of Statistics" course was taught to students of the second year of management information systems, and it was represented in a face-to-face learning environment in the classrooms and the other in an online learning environment. 


\section{- Face-to-face environment:}

The current research defines it procedurally as the environment in which learning takes place inside the classroom, the teacher meets with the students at the same time and place, for classroom practices, discussions and activities related to the educational content.

\section{Online environment:}

The current research defines it procedurally as the online learning environment on the Moodle system through virtual rooms in which classroom activities related to the educational content are practiced.

\section{- Test type:}

The current research defines it procedurally as the way in which the exam paper was placed in the "Principles of Statistics" course for students of the second year, specializing in Information Systems, and was limited to two methods, the essay test, and the objective test with the electronic correction system "Bubble Sheet".

\section{Essay test:}

The current research defines it procedurally as the way in which the exam paper was placed in the "Principles of Statistics" course for students of the second year, specializing in Information Systems, and it consisted of four essay questions that each student required to write the concepts required to answer them in writing, solve all the problems and write the steps of the solution and ensure the correctness of the solutions through a brochure Given answer.

\section{Bubble sheet system:}

The current research defines it procedurally as the way in which the exam paper was placed in the course "Principles of Statistics" for students of the second year specializing in information systems by preparing objective questions (multiple choice - true or false), and the exam was performed inside the classrooms and the correction was done electronically using the scanner.

\section{Theoretical framework}

In reviewing the theoretical framework, the researchers aimed to study the concept of learning environments with its two types: face-to-face and online, and the concept of the two types of testing: essay and bubble sheet, and to identify the results of previous studies in order to benefit from them in research procedures and in the interpretation of the results.

\section{- Learning environment:}

Learning environment refers to the way in which the classroom environment is set up. It is the many and varied scenarios of the classroom environment in which students learn. Learning environments can be traditional or virtual. There are two main categories of learning environments: a face-to-face learning environment and an online learning environment.

\section{- Face-to-Face Environment:}

A face-to-face learning environment is a traditional learning environment that takes place in the classroom, meaning that teaching, discussions, and activities take place in the classroom under the supervision of the teacher. This type of learning environment is characterized by the fact that classroom instruction is very dynamic, providing face-to-face instruction in real time., that is, it occurs synchronously in real time, and this allows students to ask questions and get immediate feedback, and it also allows the teacher to respond immediately and provide more flexible content, at the same time (Xu, D., and Jaggars, SS 2016), just as the teacher is the class leader, guiding the students through the lessons, this is beneficial because the students get one-on-one guidance and allows for differentiated teaching based on the needs of the students, active participation by all students, and personal communication between teacher and students, this allows teachers and students to establish relationships and trust building (Kemp, N., and Grieve, R. 2014), sharing personal experiences of family and home life as well as teaching and learning experiences from their own classroom (Turbill J., 2019).

One of the well-known examples and models for this type of environment is the classroom environment with all its physical components such as seats and others. The teacher presents the lesson in full with limited use of information technology. Situations of participation or the process of discussion and dialogue collectively occur in this classroom environment. The teacher has a specific period of time for interaction and is within the classroom environment.

\section{- Online Environment:}

This type of learning environment is known as elearning, which is learning that takes place via an internet-based platform, which has become a viable and attractive option with flexibility and accessibility (Wladis, C., Conway, KM, and Hachey, AC, 2015) and allows all students to participate, this type of environment focuses on studying and learning individually. This educational environment depends on technology, and this type of learning environment is characterized by synchronous and asynchronous interactions, which means either direct attendance to the lecture or return to the recorded lecture in any another time. Students work at their own pace, and this allows for student independence and enhances student responsibility by placing the workload on students. Students can also electronically communicate with the teacher, address classmates and study materials, and complete assignments from any point they can access online (Richardson, JC) , and Swan, K., 2003), just as in an online learning environment, students who do not participate in a traditional classroom can usually express their opinions and interests, since they are not in a classroom environment, calmer students may feel more comfortable participating in class dialogue without being recognized or judged, and this in turn may increase the class average grades. (Driscoll et al., 2012)

An example of this type of environment is the online virtual classroom, in which the teacher meets with students over the web or via an application such as Zoom and presents and explains the lesson or 
educational content through audio and live video broadcasts or presentations.

The most important similarities and differences between the face-to-face learning environment and the online learning environment:

Online and face-to-face education share many qualities, as students still have to attend class, learn materials, submit assignments, and complete instructional tasks, while teachers still have to design curricula, increase teaching quality, answer class questions, and motivate students to Learning, and estimating assignments (Paul J., and Jefferson F., 2019), Despite these basic similarities, there are many differences between the two environments, the most important of which is that the face-to-face learning environment is teacher-centered, and requires passive learning by the student, where the teacher gives lectures and comments while students listen, take notes and ask questions, while often The online learning environment is student-centered and requires active learning, where students independently analyze information, pose questions, and ask the teacher for clarification. In this scenario, the teacher, not the student, listens, formulates, and responds. (Salcedo, CS, 2010)

According to Daymont, T., and Blau, G. (2008), online learners learn as much from electronic interaction as from face-to-face interaction, and most meta-analyses, research reports, and previous studies have reported no significant difference in terms of the effectiveness between the online learning environment and the traditional face-to-face learning environment (Hannah T. et al., 2020), Where many studies have compared the traditional face-to-face learning environment and the online e-learning environment, and many of those studies showed no differences between these two environments, such as the study (Paul J. and Jefferson F., 2019), which dealt with the two environments over an eight-year period. Three different levels, and the results of the study showed that there was no significant difference in performance between students of online and traditional classrooms with regard to method, gender, or class rank in the Science Concepts course for non-STEM majors, and a study (Dell C., Low C., and Wilker J., 2010), which evaluated the similarities and differences between the face-to-face learning environment, and the online learning environment, and the results showed no difference in the learning success of students enrolled in the online course versus face-to-face learning environment, and the study (Lorenzo-Alvarez et al., 2019), which found that teaching radiology in the online learning environment led to academic results similar to the face-to-face learning environment, as well as the study (Hannah T. et al., 2020), whose results were that the students of the course the online training and the faceto-face course did not differ in their performance in terms of exam questions, course grades, or attitudes toward a chemistry course.
Other studies also found that the traditional face-toface learning environments outperform the online learning environments, including the study (Fischer C., et al., 2020), whose results were that students' scores were slightly lower in online courses compared to face-to-face courses, and other studies have proven the superiority of the online learning environment, including the study (Ahmed Nassif, 2020), which aimed to determine the extent of the success of distance education via the Internet in the liberated areas under Corona, as it is an alternative to traditional faceto-face education, as the results of the long-term study showed teachers in the liberated areas at all educational levels, that distance education in these areas has medium effect and effectiveness, and has achieved the continuity of the educational process in the region in the shadow of Corona.

- Test type:

The issue of evaluating students' academic achievement through tests, whether essays or objective ones, is one of the important issues that many teachers and educators care about, and everyone is keen that the students' scores on those tests actually reflect the true level of each student, and that it is due only to the extent of his knowledge of the content It is necessary to pay attention to the need to ensure that the differences between students in grades are actually due to what those tests measure, (Iman Dhaha, Fatima Musa, Inaam Kashif, 2020). However, there are many factors that positively or negatively affect the objectivity and validity of the measuring instrument and thus affect the evaluation process, and among these factors, as mentioned (Zain Radadi, 2001) is the type of test, and the most famous of these types are essay tests and objective tests in the form of Bubble Sheet.

\section{- Essay test:}

They are questions that need expressive structural answers, and through which the student's ability to arrange ideas and express them in his own words is measured, but such types of tests lack the comprehensiveness of the tested material, in addition to the difference of opinion on its validity from one corrector to another. There are two types of essay tests: Questions Restricted answers: They are questions with specific and short answers, such as questions: (define, mention...), and unlimited answers questions: they are questions that need to write an explanatory essay answer, such as questions: (Explain, explain, explain... etc.)

\section{Bubble Sheet system:}

It is a form of tests that combines the paper and electronic system, and the type of questions in this form are objective questions, which are questions characterized by their accuracy and various and easy methods of correction, the most famous of which are multiple-choice questions and true or false questions, but they are difficult to prepare, and the answers are in the form of symbols within circles, the questions are 
answered by shading the answer symbol in a circular motion, and they are corrected electronically using a scanner.

The comparison between multiple-choice questions and essay questions has been of interest to many studies, including the study of (Oyebola D., et al, 2000). The results revealed that students were better at performing on objective questions MCQ than on short essay questions, and study (Pepple D., Young L., \& Carroll R., 2010) whose results were that all students performed better on MCQs than on essay questions.

The results of the study (Nassar Y., Qaraeen K., and Abu Naba'h A., 2011) indicated that students generally prefer the multiple-choice test more than the essay test, and they believe that the test is of the multiple-choice type. Less difficult, less complex, more straightforward, more interesting, more deceptive, fairer, better in terms of expectation of success, less anxiety, and better in terms of relief. While the students indicated that both types are considered valuable. The results also indicated that students with a high achievement level are the most preferred for the essay test. Finally, students' perceptions about the multiple-choice test did not differ in a statistically significant manner according to the variables of gender and achievement level. as for the study (Eman Dhaha, Fatima Mousa, Inaam Kashif, 2020) it showed a preference for high performance for the essay test, and a preference for low for the objective test, but the preference was not an indicator of better performance Hypotheses:

as the reasons for each category differed in preference.

- There is no statistically significant difference at the level (

$\leq 0.05$ ) between the mean scores of the students of the experimental groups in the cognitive achievement results due to the effect of the interaction between the type of learning environment (face-to-face - online) and the type of test (essay - bubble sheet).

\section{Results}

To verify the validity of the research hypothesis, the averages and standard deviations of the scores of the experimental group students in cognitive achievement were calculated, as shown in the following table:

Table (2): the post-application of the scores of the experimental group students in the cognitive achievement

\begin{tabular}{ccccc}
\hline $\begin{array}{c}\text { Learning } \\
\text { Environment }\end{array}$ & Test type & Mean & $\begin{array}{c}\text { Std. } \\
\text { Deviation }\end{array}$ & N \\
\hline \multirow{4}{*}{ Face-to-Face } & Essay & $\mathbf{5 0 . 2 7}$ & 18.84 & 200 \\
\cline { 2 - 5 } & $\begin{array}{c}\text { Bubble } \\
\text { Sheet }\end{array}$ & 40.74 & 15.72 & 200 \\
\cline { 2 - 5 } Ondine & Total & 45.51 & 17.97 & 400 \\
\hline \multirow{3}{*}{ Essay } & 45.83 & 19.46 & 200 \\
\cline { 2 - 5 } & $\begin{array}{c}\text { Bubble } \\
\text { Sheet }\end{array}$ & 33.10 & 10.97 & 200 \\
\cline { 2 - 5 } & Total & 39.47 & 17.01 & 400 \\
\hline
\end{tabular}

The results of the previous table indicate the difference in the mean scores of the experimental groups students in cognitive achievement as shown in the graph:

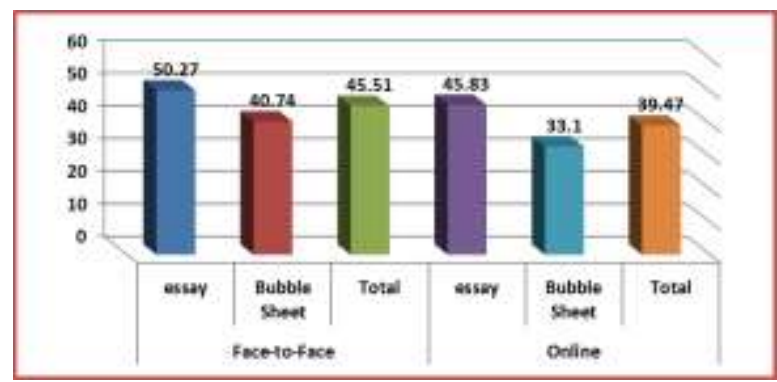

Figure (1): Average scores of experimental groups students in cognitive achievement according to the type of learning environment (face-to-face - online) and the type of test (essay - bubble sheet).

The Two-Way ANOVA method was applied to calculate the significance of the interaction between the learning environment (face-to-face - online) and the test type (essaybubble sheet) in the post application of the cognitive achievement test, and the following table summarizes these results

Table (3): Two-way ANOVA between the means of postapplication scores for the research groups in cognitive achievement

\begin{tabular}{cccccc}
\hline Source & $\begin{array}{c}\text { Type III } \\
\text { Sum of } \\
\text { Squares }\end{array}$ & df & $\begin{array}{c}\text { Mean } \\
\text { Square }\end{array}$ & F & Sig. \\
\hline $\begin{array}{c}\text { Learning } \\
\text { Environment }\end{array}$ & $\mathbf{7 2 9 6 . 3 2 0}$ & 1 & 7296.320 & 26.507 & .000 \\
\hline Test type & $\mathbf{2 4 7 7 5 . 3 8 0}$ & 1 & $\mathbf{2 4 7 7 5 . 3 8 0}$ & $\mathbf{9 0 . 0 0 6}$ & $\mathbf{. 0 0 0}$ \\
\hline $\begin{array}{c}\text { Learning } \\
\text { Environment } \\
* \text { test type }\end{array}$ & $\mathbf{5 1 2 . 0 0 0}$ & 1 & $\mathbf{5 1 2 . 0 0 0}$ & $\mathbf{1 . 8 6 0}$ & .047 \\
\hline Error & $\mathbf{2 1 9 1 1 0 . 1 2 0}$ & 796 & 275.264 & & \\
\hline $\begin{array}{c}\text { Corrected } \\
\text { Total }\end{array}$ & $\mathbf{2 5 1 6 9 3 . 8 2 0}$ & 799 & & & \\
\hline
\end{tabular}

The previous table shows the following:

1. There is a statistically significant difference at the level (0.01) between the mean scores of the experimental groups in the cognitive achievement test due to the main effect of the different learning environment (face-to-face online) - in favor of (face-to-face).

2. There is a statistically significant difference at the level (0.01) between the mean scores of the experimental group's students in the cognitive achievement test due to the main effect of the difference in the test type (essaybubble sheet) - in favor of (essay).

3. There is a statistically significant difference at the level (0.05) between the mean scores of the experimental groups in cognitive achievement due to the effect of the 
interaction between the learning environment (face-to-face - online) and the test type (essay - bubble sheet).

To determine the direction of differences between the experimental groups, the LSD test (for multiple comparisons) was applied as shown in the table:

Table (4): The differences between the averages using the LSD test for multiple comparisons between the scores of students of the experimental groups in cognitive achievement

\begin{tabular}{ccccc}
\hline & $\begin{array}{c}\text { Face to } \\
\text { face/essay } \\
(\mathbf{1})= \\
\mathbf{5 0 . 2 7}\end{array}$ & $\begin{array}{c}\text { Face to } \\
\text { face/bubble } \\
\text { sheet }(2)= \\
40.74\end{array}$ & $\begin{array}{c}\text { online/essay } \\
(3)= \\
45.83\end{array}$ & $\begin{array}{c}\text { online/ } \\
\text { bubble } \\
\text { sheet }(4)= \\
33.10\end{array}$ \\
\hline $\begin{array}{c}\text { Face to } \\
\text { face/essay } \\
(\mathbf{1}=50.27\end{array}$ & & $9.53^{*}$ & $4.44^{*}$ & $27.38^{*}$ \\
\hline $\begin{array}{c}\text { Face to } \\
\text { face/bubble } \\
\text { sheet (2) } \\
\text { 40.74 }\end{array}$ & & & $5.09 *$ & $7.64^{*}$ \\
\hline $\begin{array}{c}\text { online/essay } \\
(3)=45.83\end{array}$ & & & $12,73^{*}$ \\
\hline $\begin{array}{c}\text { online/ } \\
\text { bubble sheet } \\
(4)=33.10\end{array}$ & & & \\
\hline
\end{tabular}

It is clear from the results summarized in the previous table that there is a statistically significant difference at the level of significance $(0.05)$ between the mean scores of the experimental groups in cognitive achievement due to the effect of the interaction between the learning environment (face-to-face online) and the test type (essay - bubble sheet). The arrangement of the groups according to the averages of the post-application of the achievement test is as follows:

1. Group (1): Learning environment (face-to-face) with test type (essay)

2. Group (3): Learning environment (online) with test type (essay)

3. Group (2): Learning environment (face to face) with test type (bubble sheet)

4. Group (4): Learning environment (online) with test type (bubble sheet)

By observing the form of the results of the performance averages in their previous order, it was found that the results of student achievement differ from the average performance as shown in the results of students' success and failure, as indicated in the following table:

Table (5): Results of the success and failure of the students of the experimental groups in cognitive achievement according to the type of learning environment (face-to-face - online) and the type of test (essay - bubble sheet)

\begin{tabular}{|c|c|c|c|c|c|c|}
\hline & \multicolumn{2}{|c|}{ Success } & \multicolumn{2}{|c|}{ fail } & \multicolumn{2}{|c|}{ total } \\
\hline & $\mathbf{N}$ & $\%$ & $\mathbf{N}$ & $\%$ & $\mathbf{N}$ & $\%$ \\
\hline $\begin{array}{l}\text { Group (2): } \\
\text { Learning } \\
\text { environment } \\
\text { (face to face) } \\
\text { with test type } \\
\text { (bubble sheet) }\end{array}$ & 192 & 96 & 8 & 4 & 200 & 100 \\
\hline $\begin{array}{l}\text { Group (4): } \\
\text { Learning } \\
\text { environment } \\
\text { (online) with } \\
\text { test type } \\
\text { (bubble sheet) }\end{array}$ & 182 & 91 & 18 & 9 & 200 & 100 \\
\hline $\begin{array}{l}\text { Group (1): } \\
\text { Learning } \\
\text { environment } \\
\text { (face to face) } \\
\text { with test type } \\
\text { (essay) }\end{array}$ & 160 & 80 & 40 & 20 & 200 & 100 \\
\hline $\begin{array}{l}\text { Group (3): } \\
\text { Learning } \\
\text { environment } \\
\text { (online) with } \\
\text { test } \\
\text { (essay) type }\end{array}$ & 140 & 70 & 60 & 30 & 200 & 100 \\
\hline
\end{tabular}

The results of the previous table indicate that the students of group (2), which were taught in a (face to face) learning environmet and were tested with a (bubble sheet), outperformed by (96\%), followed by group (4), which was taught in an (online) learning environment, and it was tested with the type of test (bubble sheet) with a percentage of $(91 \%)$, then group (1), which was taught in a teaching environment (face to face), and it was tested with the type of test (essay) with a percentage of (80\%), and finally group (3), which it was taught in an (online) learning environment and was tested with an (essay) type $(70 \%)$.

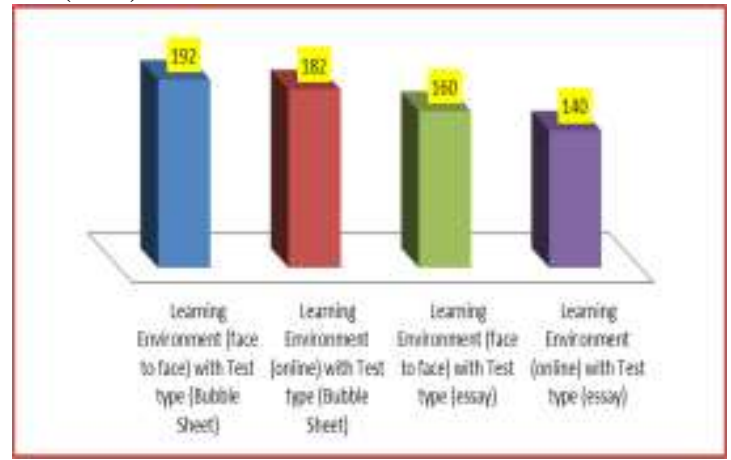

Figure (2): Results of the success of the experimental groups students in cognitive achievement according to the type of learning environment (face-to-face - online) and the type of test (essay - bubble sheet)

By extrapolating the results of the students, it was found that:

1) Students of group (2), which were taught in a learning environment (face to face) and were tested with a type of (bubble sheet) test with a success rate of (96\%), which 
ranked first in the success rates, but the number of lowachieving students is greater than the number high achieving students.

2) Students of group (4), which were taught in an (online) learning environment and were tested by a (bubble sheet) with a success rate of $(91 \%)$, which ranked second in the success rates, but the number of low-achieving students is greater than the number of high-achieving students.

3) Students of group (1), which were taught in a learning environment (face to face) and were tested by the type of test (essay) with a success rate of (80\%), which ranked third in the success rates, but the number of highachieving students is greater than the number of students underachievers.

4) Finally, group (3), which was taught in an (online) learning environment, and was tested with the type of (essay) test, with a success rate of (70\%). which ranked fourth and last in the success rates, but the number of high-achieving students is greater than the number of low-achieving students.

The following table shows the levels of performance (low - medium - high) in the results of cognitive achievement in the four groups as follows:

Table (6) levels of performance (low - medium - high) in the results of cognitive achievement

\begin{tabular}{|c|c|c|c|c|c|c|c|c|}
\hline & \multicolumn{2}{|c|}{$\begin{array}{l}\text { Success } \\
\text { rates }\end{array}$} & \multicolumn{2}{|c|}{$\begin{array}{c}\text { Low } \\
\text { performance }\end{array}$} & \multicolumn{2}{|c|}{$\begin{array}{c}\text { Medium } \\
\text { performance }\end{array}$} & \multicolumn{2}{|c|}{$\begin{array}{c}\text { High } \\
\text { performance }\end{array}$} \\
\hline & $\mathbf{N}$ & $\%$ & $\mathbf{N}$ & $\%$ & $\mathbf{N}$ & $\%$ & $\mathbf{N}$ & $\%$ \\
\hline $\begin{array}{l}\text { Group (2): } \\
\text { Learning } \\
\text { environment } \\
\text { (face to face) } \\
\text { with test type } \\
\text { (bubble sheet) }\end{array}$ & 192 & $\begin{array}{l}9 \\
6\end{array}$ & $\begin{array}{c}11 \\
4\end{array}$ & $\mathbf{5 9 . 3 8}$ & 32 & 16.6 & 46 & 24 \\
\hline $\begin{array}{l}\text { Group (4): } \\
\text { Learning } \\
\text { environment } \\
\text { (online) with } \\
\text { test type } \\
\text { (bubble sheet) }\end{array}$ & 182 & $\begin{array}{l}9 \\
1\end{array}$ & $\begin{array}{c}12 \\
0\end{array}$ & 65.9 & 46 & 25.8 & 16 & 8.8 \\
\hline $\begin{array}{l}\text { Group (1): } \\
\text { Learning } \\
\text { environment } \\
\text { (face to face) } \\
\text { with test type } \\
\text { (essay) }\end{array}$ & 160 & $\begin{array}{l}8 \\
0\end{array}$ & 14 & 8.75 & 38 & 23.75 & 108 & 67.5 \\
\hline $\begin{array}{l}\text { Group (3): } \\
\text { Learning } \\
\text { environment } \\
\text { (online) with } \\
\text { test } \\
\text { (essay) }\end{array}$ & 140 & $\begin{array}{l}7 \\
0\end{array}$ & 17 & 12.1 & 39 & 27.9 & 84 & 60 \\
\hline
\end{tabular}

Based on the results of the previous table, it can be said that:

- The type of objective test with (bubble sheet system), in which the student shades in the answer sheet on all test vocabulary. It was found that the effect of guessing may be on a high degree for students, which had the greatest impact on high success rates and low performance.

- The type of essay test, which requires the student to take steps to solve problems, reach results and verify their validity, on all test questions. it emphasized that the success rates are low compared to the bubble sheet type, but the level of performance is high.

- The face-to-face learning environment type, the performance level is higher than the online learning environment type.

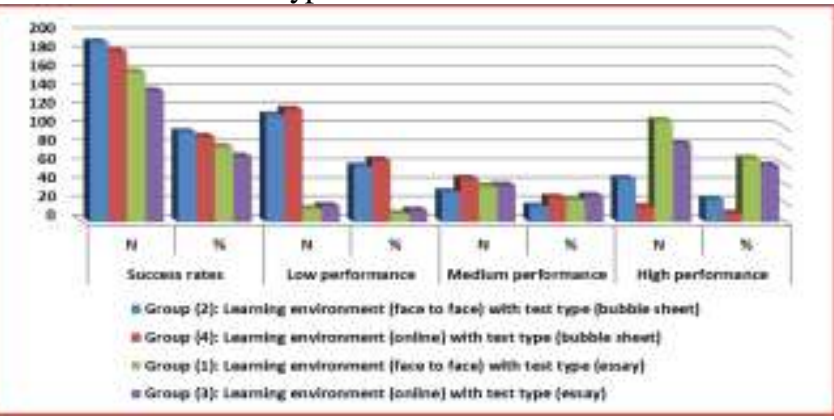

Figure (3): Levels of performance (low - medium - high) in the results of cognitive achievement

Based on the foregoing, the research hypothesis can be rejected, which states: There is no statistically significant difference at the

level $(\leq 0.05)$ between the mean scores of students of the experimental groups in cognitive achievement due to the effect of the interaction between the learning environment (face to face - online) and the type of test (essay -bubble sheet), and the alternative hypothesis accepted, which states: There is a statistically significant difference at the level $(\leq 0.05)$ between the mean scores of the experimental groups students in cognitive achievement due to the effect of the interaction between the learning environment (face-to-face - online) and the type of test (essay -bubble sheet).

\section{Discussing}

The results of the research revealed the superiority of the students of group (2), which was taught in a learning environment (face to face) and was tested with a type of (bubble sheet), followed by group (4), which was taught in a learning environment (online) and was tested with a type of test (bubble sheet), then group (1) which was taught in a learning environment (face to face) and was tested with the type of test (essay), and finally group (3) which was taught in a learning environment (online) and tested with the type of test (essay).The researchers attribute this to:

Passing the final test with a score of (22.5) out of a total of (75) degrees, equivalent to $30 \%$, according to the list used.

Not controlling the effect of guessing on students' answers to the tests, as if the student responds to the statements as completely (true) or (false), the students receive $50 \%$ of the total question scores, which is a contributing factor to the student's success in the final test.

- Ease of cheating and the transfer of answers and their circulation among students during the examination in the event of lack of full control of the committee observers.

- The questions bank on the Moodle system that is being reviewed by the student and that it contains a low number of test vocabulary, on which the instructor relies (total) approval during the setting of the test. 
- Not setting a table of specifications for the exam and its codification, which leads to the ease of some exams and the lack of consideration for the coefficient of ease, difficulty and coefficient of discrimination.

\section{Recommendation}

In light of the results of the current research, the following set of recommendations can be made:

1) The necessity of holding training workshops for faculty members and members of the supporting staff in universities to deal with electronic learning environments such as the Moodle system.

2) Enriching the university library with books dealing with electronic learning environments, the mechanism of their use and their impact on the teaching and learning processes.

3) Developing measurement tools and assessment tools, especially tests, to suit e-learning environments.

4) The necessity of holding training workshops for university faculty members on how to formulate and set objective tests and systems for their correction and to exclude the effect of guesswork among students.

5) Legalization of tests before their application.

6) Increasing the vocabulary of question banks for each course.

7) Increasing the test alternatives and making more than one valid alternative available until the effect of guesswork is excluded.

8) Reconsider the success rate (30\%) set by the Ministry in the list used and increase it.

\section{References}

[1] Ahmed Nassif (2020). The efficacy of distance education as an alternative to traditional education in liberated areas from the point of view of teachers. Rehan Journal for Scientific Publishing, 1, 28-52.

[2] Daymont T., \& Blau G. (2008). Student performance in online and traditional sections of an undergraduate management course. J. Behav. Appl. Manag. 9, 275294.

[3] Dell C., Low C., and Wilker J. (2010). Comparing student achievement in online and face-to-face class formats. J. Online Learn. Teach. Long Beach 6, 3042.

[4] Driscoll A., Jicha K., Hunt A. N., Tichavsky L., and Thompson G. (2012). Can online courses deliver inclass results? A comparison of student performance and satisfaction in an online versus a face-to-face introductory sociology course. Am. Social. Assoc. 40, 312-313. Doi: 10.1177/0092055X12446624

[5] Fischer C., et al. (2020). Effects of course modality in summer session: Enrollment patterns and student performance in face-to-face and online classes. The Internet and Higher Education 45-100710.

[6] Hannah T., Katrina L., Luke D., April B., and Roslyn M. (2020). Comparison of student attitudes and performance in an online and a face-to-face inorganic chemistry course. Chem. Educ. Res. Pract., $21,168$.

[7] Iman Duha, Fatima Musa and Inaam Kashef. (2020). Experiential wisdom and goal orientations as predictive factors of performance on essay and objective tests among a sample of female students of the Faculty of Education - Damanhour University. Journal of the Faculty of Education, Port Said University, 31 .

[8] Kemp N., \& Grieve R. (2014). Face-to-Face or faceto-screen? Undergraduates' opinions and test performance in classroom vs. online learning. Front. Psychol. 5:1278. Doi: 10.3389/fpsyg.2014.01278

[9] Lorenzo-Alvarez R., Rudolphi-Solero T., RuizGomez M. J., and Sendra-Portero F. (2019). Medical student education for abdominal radiographs in a 3D virtual classroom versus traditional classroom: a randomized controlled trial. Am. J. Roentgenol. 213, 644-650. Doi: 10.2214/AJR.19.21131

[10] Nassar Y., Qaraeen K., and Abu Naba'h A. (2011). Secondary School Students' Perceptions of Essay and Multiple-Choice Type Exams. Educational Sciences. 10.35516/0102-038-001-023.

[11] Oyebola D., Adewoye O., Lyaniwura J., Alada A., Fasanmade A., and Raji Y. (2000). A comparative study of student's performance in preclinical physiology assessed by multiple choice and short essay questions. African journal of medicine and medical sciences .29(3-4):201-205.

[12] Paul J., \& Jefferson F. (2019). A Comparative Analysis of Student Performance in an Online vs. Face-to-Face Environmental Science Course From 2009 to 2016. Front. Comput. Sci. 1:7. Doi: 10.3389/fcomp.2019.00007

[13] Pepple D., Young L., and Carroll R. (2010). A comparison of student performance in multiplechoice and long essay questions in the MBBS stage I Physiology examination at the University of the West Indies (Mona Campus). Adv Physiol Educ. 34: 86-89.

[14] Richardson J., \& Swan K. (2003). Examining social presence in online courses in relation to student's perceived learning and satisfaction. J. Asynchr. Learn. 7, 68-88.

[15] Salcedo C. (2010). Comparative analysis of learning outcomes in face-to-face foreign language classes vs. language lab and online. J. Coll. Teach. Learn. 7, 4354. doi: $10.19030 /$ tlc. v7i2.88

[16] Turbill J. (2019). Transformation of Traditional Face-to-Face Teaching to Mobile Teaching and Learning: Pedagogical Perspectives. In: Zhang Y., Cristol D. (eds) Handbook of Mobile Teaching and Learning. Springer, Singapore. https://doi.org/10.1007/978-981-13-2766-7_54

[17] Wladis C., Conway K., and Hachey A. (2015). The online STEM classroom-who succeeds? An exploration of the impact of ethnicity, gender, and non-traditional student characteristics in the 
community college context. Common. Coll. Rev. 43, 142-164. Doi: 10.1177/0091552115571729

[18] Xu D., \& Jaggars S. (2016). Performance gaps between online and face-to-face courses: differences across types of students and academic subject areas. J. Higher Educ. 85, 633-659. Doi: 10.1353/jhe.2014.0028

Zain Hassan Radadi. (2001). Experiential wisdom and its relationship to the student's type, specialization, and academic achievement. Journal of the Faculty of Education. Zagazig University, 39, 134.

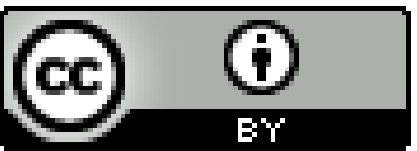

